\title{
Impact of Work Engagement on Performance in Indian Higher Education System
}

\author{
Manish Gupta ${ }^{1}$, Anitha Acharya ${ }^{1} \&$ Ritu Gupta ${ }^{1}$ \\ ${ }^{1}$ IBS Hyderabad, a Constituent of IFHE, Deemed to be University, Telangana, India \\ Correspondence: Manish Gupta, IFHE Campus, Donthanapally. Shankarapalli Road, Hyderabad, 501203, \\ Telangana, India. Tel: 91-084-1723-6660. E-mail: manish.gupta.research@gmail.com
}

Received: December 12, 2014

Accepted: January 15, 2015 Online Published: February 25, 2015

doi:10.5539/res.v7n3p192
URL: http://dx.doi.org/10.5539/res.v7n3p192

\begin{abstract}
The moments in which employees attach themselves with their work roles are called as the moments of engagement (Kahn, 1992). The number of higher educational institutions is rapidly growing in India to cater to the increasing demand for advanced studies (KPMG, 2014). As a result, Indian academia is facing the challenge of keeping academics engaged so that academics can happily and efficiently perform a larger role. So, this study examines the influence of job resources on engagement along with how the interaction among job resources and perceived autonomy impacts performance in service delivery. We also examine the mediating role of work engagement between the job resources and service employee performance relationship. Two hundred sixty one academics elected from different Indian universities were asked to rate themselves on the support, autonomy and engagement scales. Further, 261 students were asked to rate the performance of these academics. Structural equation modeling was used to test the formulated hypotheses. The results suggest that work engagement mediates the relationship between supervisory support and service employee performance. Moreover, perceived autonomy moderates relationship between co-worker support and work engagement relationship. These findings extend the theoretical understanding of engagement enhancing the performance in service delivery as reflected in the feedback from students. Results also urge universities to make policies that enhance coworker and supervisory support which can create a culture of co-operation. Certain limitations and future research directions of this study have also been discussed in greater detail.
\end{abstract}

Keywords: academics, co-worker support, employee performance, higher education, India, job resources, perceived autonomy

\section{Introduction}

In the era of globalization when going abroad for studies is affordable for many Indians, universities in India are increasingly facing intense competition from the foreign universities. Given the fact that as many as 350,000 is the estimated short fall in the Indian universities' faculty members in 2015 (KPMG, 2014), almost eight lakh Indian students spent more than INR 100billion on studies abroad (ASSOCHAM, 2012) in the year 2012-13 alone. In order to cope-up with such a shortage of supply and competitive environment, the universities are devising new ways and means to attract and retain faculties and are increasingly following the philosophy of "academic capitalism". According to this philosophy, academia functions like a profit-oriented firm in that, students are the customers, employees are academics and the employer is the management of the university (Rhoades \& Slaughter, 2004). This trend of academic capitalism in India is new and shocking to its critiques because it can make not so rich non-profit organizations devoid of quality faculty. Nevertheless, researchers argue that the remedy lies in the concept of work engagement as it advocates that motivation is not restricted to monetary benefits only.

Employee engagement is the sum of meaningfulness, safety and availability which an engaged employee experiences within a holistic appraisal of their wellbeing en route to bringing their full selves into work (Khan, 1990). Employee engagement is the steps taken by organizations to manage their workforce, rather than a psychological state experienced by employees in the performance of their work (Truss et al., 2012). Employee engagement is a very powerful factor used to measure the company's vigor and direction towards superior performance (Mokaya \& Kipyegon, 2014). Employee engagement is the main focus of both business entrepreneurs and academic researchers (Mokaya \& Kipyegon, 2014). If companies want to gain competitive 
advantage then employee engagement is the most useful tool for achieving it (Baumruk, 2004). Employee engagement is concerned with creating expectation for employees to attach with their superiors, coworkers and the company in which they are working (Mokaya \& Kipyegon, 2014).

Employee engagement is associated positively with customer loyalty, productivity, profitability and customer satisfaction, and associated negatively to employee turnover (Harter, Schmidt, \& Hayes, 2002). A study conducted by Perrin (2008) showed that companies that hired highly engaged employees had a better spread in their operating and net margin compared to companies that hired highly disengaged employees. In spite of its theoretical and managerial consequences, engagement of service employee has received very less empirical examination in the literature of work engagement. In the current study, we have used the Job Demand-Resources model (Ashill \& Rod, 2011; Babakus, Yavas, \& Ashill, 2009) to establish and test a conceptual model that explains how employees who get support from management provide better performance.

\section{Literature Review}

Managers in the service sector are faced with lot of challenges. The span of control of these managers continues to grow, at the same time the demand for customer satisfaction has also been on the rise (Schlesinger \& Heskett, 1991). With more employees to manage and greater demands on performance, service sector managers feel restricted in their ability to develop relationships with employees (Anderson \& Galinsky, 2006). Undoubtedly, managing employees in a service sector setting provides unique challenges for managers, particularly if the manager attempts to develop quality dyadic relationships with employees (Anderson \& Galinsky, 2006). Managing employees in the service sector is different than managing employees in the manufacturing sector (Bowen \& Ford, 2002) on several occasions. First, the process of delivering a service involves the customer in the production process. Second, service employees must respond to each situation in a unique manner. Third, emotional labor is an important part of the work in a service setting. Finally, service employees not only perform work, but they also manage the service delivery process (Gershuny \& Miles, 1983). It is the human element in the service delivery that distinguishes management practice in a service setting from management practice in a manufacturing setting (Bowen \& Ford, 2002). An employee in a service setting has direct contact with customers (Moore, 1985). This customer contact generally takes place between employees at the lowest levels of the organization (Moore, 1985). If a service sector employee is frustrated with the work environment, this frustration does not only influence the employee's performance on the manufacturing line, it can directly influence a customer's perception of the organization (Schlesinger \& Heskett, 1991).

It is important for managers in the service setting to understand how their behavior influences employees' which in turn affects the performance of the employees' (Humphreys, 2002; Piercy et al., 2001). The concept of relational coordination seems to gather the spirit of high-involvement management practices on the individual manager level. Relational coordination addresses the specific managerial behaviors, rather than organizational policies, that influence the dyadic employer-employee relationship (Sorenson \& Savage, 1989). Relational coordination suggests that it is not listening to an employee that makes the difference, but actually sharing information with them and including them in problem solving makes the difference. This communication is distinct from communication in the human relations paradigm in that a manager actively shares information with the employee that will help improve his or her performance on the job and vice versa. Bakker, Hakanen, Demerouti and Xanthopoulou (2007) used job demands-resources model, to study whether resources act as buffers and reduce the negative relationship between student misconduct and work engagement. In addition, they used conservation of resources theory, to see whether work engagement is influenced by job resources particularly when faculties are confronted with high levels of student misconduct. In the following section we present the development of hypothesis.

\subsection{Support and Work Engagement}

Coworker support is the help which the employees believe they will get from their fellow workers so that they are able to perform their job in an efficient way (Susskind, Kacmar, \& Borchgrevink, 2003). The help which the coworkers provide to the employees is very important since they not only help in performing the job but also they activate their self-esteem, and boost their moral (Xanthopoulou et al., 2007). The support which they receive has the motivational potential and enhances employees' feelings of, absorption, dedication, and vigor (Bakker \& Demerouti, 2007, 2008). Therefore, we propose the following hypothesis:

Hypothesis 1 (H1): Coworkers support is positively related to engagement.

Engagement has been defined as "a positive, fulfilling, work-related state of mind that is characterized by vigor, dedication, and absorption" (Schaufeli, Salanova, Gonzalez-Roma, \& Bakker, 2002, p. 74). A service employee who is spirited, keen and excited is termed as a person who is engaged to his or her work and disengaged person 
is one who is indifferent, mechanical, alienated and withdrawn from his or her job (Gupta \& Kumar, in press; Salanova, Agut, \& Peiro, 2005). Vigor refers to eagerness to expend effort and energy in one's work and to be buoyant and perpetual when faced with difficulties. Dedication means a sense of devotion, dignity, motivation and daring (Schaufeli et al., 2002). Absorption refers to being fully engrossed and satisfied with one's work in such a way that time passes quickly and finding it difficult to detach oneself from work (Salanova et al., 2005). Previous research has envisioned the notion of engagement from job satisfaction and job. In fact, Rich et al. (2010) have show that engagement affects task performance positively even after controlling for job involvement, job satisfaction, and intrinsic motivation.

Supervisory support is the work related assistance which the supervisor provides to their employees in performing their job (Susskind, Kacmar, \& Borchgrevink, 2003). Employees who receive adequate support from their superiors believe that support is a part of the organizational function. This was supported by Wayne, Shore and Liden's (1997) where the quality of leader member exchange has a strong effect on perceived organizational support offered to coworkers. Supervisory support is very important since they motivate employees to be engaged in their work at the workplace. If we have a supervisor who is a good listener and who supports employees during unforeseen circumstances, this can boost the morale of the employees (DeConinck, 2010). Also, supervisory support can ease the stress and apprehension which is demanded for the effective performance of the job (Babin \& Boles, 1996). The employees also remain engaged to their work (Sand \& Miyazaki, 2000). On the contrary, if the supervisory support is inadequate, then employees feel isolated, discontented and powerless and they will start questioning their importance to the organization. In the hypothesized model we propose that support from supervisors will help in work engagement.

Hypothesis 2 (H2): Supervisory support is positively related to engagement.

\subsection{Work Engagement and Service Employee Performance}

When employees are more engaged in their work, they will find their work to be easier and interesting rather than challenging and will be more committed, robust and absorbed in their jobs (Crawford, LePine, \& Rich, 2010). This will lead employees to think in a positive manner and will help them in serving their customers well (Harter et al., 2002). In a study by Sonnentag (2003), it was found that engagement influences in-role behavior, proactive behavior and also organizational citizen behavior. This shows that employees who are engaged will have a broader perspective of their role and will reach out to broader set of activities in their jobs. This implies that, engagement will have a positive effect on how employees perform their duties, including offering superior assistance to customers. Engagement is positively related to important business performance consequences like customer satisfaction, customer loyalty, positive word of mouth, profitability, and increased market share (Schneider, Macey, Lee, \& Young, 2009). We expect engaged employees to be helpful, observant to customer problems, timely delivery and will recommend products which best meets customer requirements.

Hypothesis 3 (H3): Work engagement is positively related to customers' evaluation of service employee performance

\subsection{Mediating Role of Engagement}

As observed in the previous discussion, $\mathrm{H} 1, \mathrm{H} 2$ and $\mathrm{H} 3$ indicate that engagement should mediate the relationship between (a) supervisor support and employee performance and (b) coworker support and employee performance (Menguc et al., 2012). Thus, we explore engagement as a mediator because resources like coworker support and supervisor support are important concepts from the point of view of the customer. That is, customers will not be able to appraise how the service employees are treating them based on the resources that employees receive from their managers. The resources which they receive are too distant from employee-customer interactions to be predictors of performance by service employee. Hence concluding performance based on resources will be inefficient unless the resource provides impetus for greater levels of employee engagement. Hence, we state that engagement is a proximal construct that reflects how employees feel about the resources they receive, and influences employee performance. Thus, we hypothesize:

Hypothesis 4 (H4): Engagement mediates the relationship between supervisory support and customers' evaluation of service employee performance

Hypothesis 5 (H5): Engagement mediates the relationship between coworker support and customers' evaluation of service employee performance.

\subsection{Moderating Role of Perceived Autonomy}

Perceived autonomy at the employees' level is the degree of independence, resilience, vigilance and control, which the employees have in performing their jobs (Hackman \& Oldham, 1976). When perceived autonomy is 
high, employees will feel motivated, and capable of performing their jobs (Marinova, Ye, \& Singh, 2008). This means that as and when employees have higher supervisor support their engagement will be high. Employees may internalize work rules, procedures and standards when they perceive more autonomy (Stone, Deci, \& Ryan, 2009). Employees can grasp and integrate the task which is given to them by their supervisors when perceived autonomy is high. This advocates that at high level of perceived autonomy, supervisory support will have a positive effect on engagement. We hypothesize that there is an integral relationship between perceived autonomy and supervisory support.

Hypothesis 6 (H6): Perceived autonomy positively moderates the relationship between supervisory support and engagement.

Bakker and Demerouti (2007) found that resources are very important to deal with job demands. This was supported by a study conducted by Hackman and Oldham (1980) on characteristics of job which emphasized on motivational potential of a job resource at the task level, including feedback, task significance and autonomy. In addition, this is in accordance with conservation of resources theory (Hobfoll, 2001) which stated that the prime human motivation is directed towards the preservation and accumulation of resources. These are valued in their own right as they are the means to the achievement or protection of other valued resources (Bakker \& Demerouti 2007). The resources required to perform the job are located at every level of the organization at large (e.g., career opportunities), in the interpersonal and social relations (e.g. co-worker and supervisor support), the organization of work (e.g. job clarity, participation in decision making), and at the task level (e.g., performance feedback, task identity, autonomy) (Bakker \& Demerouti, 2007). In a study by Kahn (1992) it was found that jobs which are high on the core job characteristics provide individuals with the space and impetus to bring more of themselves into their work. May et al. (2004) found that job enrichment was positively related to meaningfulness which mediated the relationship between job enrichment and engagement. The control and workload conditions from the Maslach et al. (2001) model suggested the importance of job characteristics for engagement. Moreover, job characteristics, feedback, have been consistently related to burnout (Maslach et al., 2001). It is also argued that engaged employees have high level of energy and are dedicated to work. Past researches have indicated that job resources like co-worker support and supervisor support enhances work engagement, which in turn results in better performance (Bakker \& Demerouti, 2007). We therefore hypothesize that:

Hypothesis 7 (H7): Perceived autonomy positively moderates the relationship between coworker support and engagement.

We have identified two gaps after reviewing the relevant literature. First, the challenges which the employees face while they are doing their job of satisfying customer's needs and at the same time fulfilling management's expectations, coupled with scarce job resources, make engagement very difficult in the service context (Ashill \& Rod, 2011). If employees are disengaged, then their negative mindset can be very deadly and will reflect on how they treat their customers. Therefore, it is important that we understand what types of resources like social, task and organizational are needed to motivate service employee engagement. Second, previous studies have focused on engagement from an internal context by studying how engagement affects employee attitude and performance (Rich, LePine, \& Crawford, 2010). In comparison, we are exploring employee engagement from an external perspective to understand how employee engagement affects customers' views of the service performance they receive. In the following section we discuss the methodology adopted to test the stated hypothesis. It is evident from the aforementioned literature review that research on Job Demand Resources-work engagement-performance in the context of Indian academia is still at its nascent stage. In that, coworker support as one of the Job Demand Resources component evaluated based on the feedback of others and Indian higher education viewed from the lens of academic capitalism is an important area for research which this study has objectivized. 


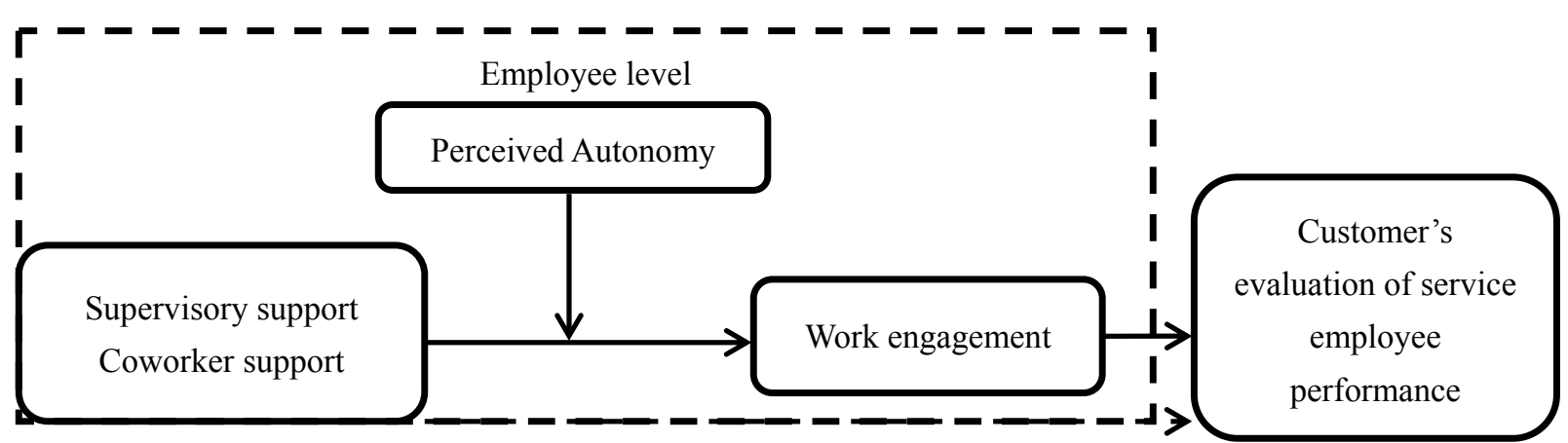

Figure 1. The hypothesized model

\section{Methodology}

\subsection{Sample}

Data were collected from academicians and students from ten universities, five of these were located in southern India and other five in northern India. An online survey link was created for the data collection which was forwarded to the head of these institutions to request their participation in the study. After a reminder, we received 261 responses from academics. An equal number of students of those universities were then asked to fill the questionnaire for service employee performance. The descriptive statistics and demographics for academicians and students are shown in Table 1.

\subsection{Measures}

For measuring work engagement, perceived autonomy, supervisor support and coworker support, Salanova et al.'s, (2005) seventeen-item scale, Spreitzer's (1995) three-item scale, House's (1981) three-item scale and Susskind, Kacmar and Borchgrevink's (2003) three-item scale respectively were used. Seven point Likert type scale was used to capture the variance in responses.

\subsection{Data Analysis and Results}

Bi-variate correlations were calculated in order to ensure that there is no multi co-linearity issue and the constructs are reasonably associated with each other. Mediation of work engagement was checked after obtaining model fit by using IBM AMOS software. Interaction effects for both: supervisory support-work engagement and coworker support-work engagement were checked using SPSS linear regression tool. Following the principle of parsimony, supervisor feedback was replaced with coworker support in the current study.

As shown in Table 1, all the correlations among latent variables were significant at $p<.01$ and were also reliable with all the Cronbach's alphas scoring more than 0.80 . The reliable and workable data took us to the next step to further investigate the role of work engagement and perceived autonomy as a mediator and a moderator respectively. The results of structural equation modeling indicated a good model fit $(\mathrm{CFI}=0.91 ; \mathrm{IFI}=0.91$; RMSEA $=0.07$ and $\chi^{2} / \mathrm{df}=2.32$ ). However, when the work engagement was removed as a mediator, CFI (.946), IFI (.947) increased but at the same time $\chi 2 / \mathrm{df}$ decreased and RMSEA became insignificant. Hence, we infer that work engagement is an important contributor to the model and cannot be excluded. This finding is in line with the study conducted by Menguc et al.'s (2013).

Table 1. Descriptive statistics and zero-order correlations for aggregated data

\begin{tabular}{llllllll}
\hline & Mean & SD & 1 & 2 & 3 & 4 & 5 \\
\hline Academics Age & 38.54 & 9.1 & & & & & \\
Work experience in the current organization (Years) & 04.97 & 3.0 & & & & & \\
Total Work Experience (Years) & 11.79 & 6.4 & & & & & \\
Student Age & 23.51 & 3.0 & & & & & \\
1. Supervisory support & 5.42 & 1.2 & $(.87)$ & & & & \\
2. Customer support & 5.64 & 0.9 & $.49^{* *}$ & $(.80)$ & & \\
3. Perceived autonomy & 4.79 & 1.4 & $.54^{* *}$ & $.47^{* *}$ & $(.89)$ & & \\
\hline
\end{tabular}




\begin{tabular}{llllllll}
\hline 4. Service employee performance & 5.17 & 1.2 & $.58^{* *}$ & $.56^{* *}$ & $.68^{* *}$ & $(.94)$ & \\
5. Work engagement & 5.73 & 0.8 & $.62^{* *}$ & $.50^{* *}$ & $.49^{* *}$ & $.61^{* *}$ & $(.93)$ \\
\hline
\end{tabular}

Note. ${ }^{* *} p<.01$ (two-tailed), $\mathrm{n}=261$, Brackets represent Cronbach's alpha values

Table 2 reveals a significantly positive impact of supervisory support and coworker support on work engagement, and that of work engagement on service employee performance. These results indicate support for H1, H2 and H3 hypotheses and are in sync with the Menguc et al.'s study except for H1 hypothesis. In our opinion it could be because of the strong mentorship programs in the academia as opposed to retail or because of Indian culture of knowledge transfer from elders to younger generation as opposed to West.

Table 2. Unstandardized path coefficients of the proposed model $(n=261)$

\begin{tabular}{|c|c|c|c|c|c|c|c|c|}
\hline \multirow{2}{*}{ Relationship } & \multicolumn{2}{|c|}{$\begin{array}{l}\text { Model } 0 \\
\text { (Default model) }\end{array}$} & \multicolumn{2}{|c|}{$\begin{array}{l}\text { Model } 1 \\
\text { (Without } \mathrm{SS} \rightarrow \mathrm{WE} \text { ) }\end{array}$} & \multicolumn{2}{|c|}{$\begin{array}{l}\text { Model } 2 \\
\text { (Without } \mathrm{CS} \rightarrow \mathrm{WE} \text { ) }\end{array}$} & \multicolumn{2}{|c|}{$\begin{array}{l}\text { Model } 3 \\
\text { (Without WE) }\end{array}$} \\
\hline & Estimate & C.R. & Estimate & C.R. & Estimate & C.R. & Estimate & C.R \\
\hline $\mathrm{PA} \rightarrow \mathrm{CS}$ & $\begin{array}{l}0.44 \\
(0.05)^{\mathrm{a}}\end{array}$ & 8.44 & $\begin{array}{l}0.45 \\
(0.05)^{\mathrm{a}}\end{array}$ & 8.47 & $\begin{array}{l}0.46 \\
(0.05)^{\mathrm{a}}\end{array}$ & 8.70 & $\begin{array}{l}0.45 \\
(0.05)^{\mathrm{a}}\end{array}$ & 8.48 \\
\hline $\mathrm{PA} \rightarrow \mathrm{SS}$ & $\begin{array}{l}0.54 \\
(0.06)^{\mathrm{a}}\end{array}$ & 8.97 & $\begin{array}{l}0.57 \\
(0.06)^{\mathrm{a}}\end{array}$ & 9.29 & $\begin{array}{l}0.55 \\
(0.06)^{\mathrm{a}}\end{array}$ & 9.01 & $\begin{array}{l}0.56 \\
(0.06)^{\mathrm{a}}\end{array}$ & 9.15 \\
\hline $\mathrm{CS} \rightarrow \mathrm{WE}$ & $\begin{array}{l}0.21 \\
(0.05)^{\mathrm{a}}\end{array}$ & 4.50 & $\begin{array}{l}0.27 \\
(0.05)^{\mathrm{a}}\end{array}$ & 5.29 & n.a. & n.a. & n.a. & n.a. \\
\hline $\mathrm{PA} \rightarrow \mathrm{WE}$ & $\begin{array}{l}0.14 \\
(0.04)^{a}\end{array}$ & 3.19 & $\begin{array}{l}0.28 \\
(0.04)^{a}\end{array}$ & 6.63 & $\begin{array}{l}0.19 \\
(0.04)^{\mathrm{a}}\end{array}$ & 4.84 & n.a. & n.a. \\
\hline $\mathrm{SS} \rightarrow \mathrm{WE}$ & $\begin{array}{l}0.31 \\
(0.05)^{\mathrm{a}}\end{array}$ & 6.54 & n.a. & n.a. & $\begin{array}{l}0.36 \\
(0.05)^{\mathrm{a}}\end{array}$ & 7.13 & n.a. & n.a. \\
\hline $\mathrm{SS} \rightarrow \mathrm{SP}$ & n.s. & 1.51 & $\begin{array}{l}0.17 \\
(0.05)^{\mathrm{a}}\end{array}$ & 3.19 & n.s. & n.a. & $\begin{array}{l}0.41 \\
(0.06)^{a}\end{array}$ & 6.48 \\
\hline $\mathrm{WE} \rightarrow \mathrm{SP}$ & $\begin{array}{l}0.78 \\
(0.15)^{\mathrm{a}}\end{array}$ & 5.12 & $\begin{array}{l}0.77 \\
(0.12)^{\mathrm{a}}\end{array}$ & 6.29 & $\begin{array}{l}0.78 \\
(0.14)^{\mathrm{a}}\end{array}$ & 5.46 & n.a. & n.a. \\
\hline $\mathrm{CS} \rightarrow \mathrm{SP}$ & $\begin{array}{l}0.20 \\
(0.07)^{b}\end{array}$ & 3.01 & $\begin{array}{l}0.17 \\
(0.07)^{\mathrm{C}}\end{array}$ & 2.52 & $\begin{array}{l}0.25 \\
(0.06)^{\mathrm{a}}\end{array}$ & 4.21 & $\begin{array}{l}0.43 \\
(0.07)^{\mathrm{a}}\end{array}$ & 6.01 \\
\hline
\end{tabular}

Note. Values in parenthesis represent standard error, n.s. $=$ not significant, C.R. $=$ critical ratio, $\mathrm{CS}=$ coworker support, $\mathrm{SS}=$ supervisory support, $\mathrm{WE}=$ work engagement, $\mathrm{PA}=$ perceived autonomy, $\mathrm{SP}=$ service employee performance, n.a. $=$ not applicable, ${ }^{\mathrm{a}} \mathrm{p}<.001,{ }^{\mathrm{b}} \mathrm{p}<.01,{ }^{\mathrm{c}} \mathrm{p}<.05$.

\subsubsection{Mediation}

Further, investigation of results reveals significant mediation by work engagement in the customers' evaluation of service employee performance and supervisory support relationship indicating support for hypothesis $\mathrm{H} 4$. This finding is however in contrast of what original study found wherein; supervisory support was not found to be significantly related to customers' evaluation of service employee performance without mediator. As opposed to significant supervisory support-performance mediation result of this study, work engagement did not share significant variance with the construct "coworker support" and customers' evaluation of service employee performance (see Table 2). However, work engagement was strongly and significantly correlated to both coworker support and customers' evaluation of service employee performance. Therefore, further analysis for partial mediation was carried out. With the help of Sobel test, Aroian test and Goodman test that resulted in the corresponding statistics of 3.267, 3.231 and 3.304, all significant at $p<.01$. This confirms that work engagement partially mediates the coworker support-customer evaluation relationship. Unlike previous studies, this finding is unique to this study. The results, hence, support hypothesis- $\mathrm{H} 5$ partially. 


\subsubsection{Moderation}

Table 3 describes the value of path coefficients and interaction effects thereby capturing the moderating role of perceived autonomy. In the original study, supervisory support was found to have positive effect on work engagement at high levels of perceived autonomy whereas mixed results were obtained in the current study. The effect of moderation by perceived autonomy was found significant at 0.05 levels for the coworker support-work engagement relationship but not for the supervisory support-work engagement relationship. Therefore, the results indicate support for hypothesis - $\mathrm{H} 7$ but not for hypothesis - $\mathrm{H} 6$.

Table 3. Moderation effects of perceived autonomy in the relationship between support and engagement

\begin{tabular}{|c|c|c|c|c|c|}
\hline \multirow{2}{*}{ Model } & \multicolumn{2}{|c|}{ Unstandardized Beta } & \multirow{2}{*}{$\begin{array}{l}\text { Standardized } \\
\text { Beta }\end{array}$} & \multirow{2}{*}{$\mathrm{t}$} & \multirow{2}{*}{ Sig. } \\
\hline & $\beta$ & s.e. & & & \\
\hline (Constant) & -0.026 & 0.038 & & -0.68 & n.s. \\
\hline Supervisory support & 0.310 & 0.091 & 0.498 & 3.40 & .001 \\
\hline Customer support & -0.071 & 0.128 & -0.083 & -0.55 & n.s. \\
\hline Perceived autonomy & 0.078 & 0.031 & 0.144 & 2.49 & .013 \\
\hline $\begin{array}{l}\text { Perceived autonomy } \\
\text { Supervisory support }\end{array}$ & -0.009 & 0.020 & -0.060 & -0.43 & n.s. \\
\hline $\begin{array}{l}\text { Perceived autonomy } \times \text { Customer } \\
\text { support }\end{array}$ & 0.058 & 0.028 & 0.318 & 2.11 & .036 \\
\hline
\end{tabular}

Note. n.s. $=$ not significant.

\section{Discussion}

The results of this study indicate significant mediating role of work engagement between job resources and performance. Further, the results of the current study do not support the argument that perceived autonomy moderates supervisory support and work engagement relationship. This could be because of the distant nature of interaction with supervisors in academia. The authors argue that it could be because the supervisory support and work engagement are so strongly related to each other that change in the level of perceived autonomy does not affect their relationship significantly (Hakanen, Bakker, \& Schaufeli, 2006). Moreover, the present study supports the results of Ashill and Rod (2011), indicating a positive relationship between supervisory support and work engagement relationship as opposed to the results reported by Menguc et al.'s (2013). However, there is a reason for deviance as the use of both, supervisory support and supervisory feedback may make the supervisory support redundant. This could lead to only one construct being able to contribute significantly to the entire model.

The results reported herein make important contributions to the literature on employee engagement. In particular, the study contributes to three theories in unique ways. First, it extends and validates the existing Job Demand-Resource model in the context of Indian academia, where, the customer feedback is also incorporate. Second, it confirms the impact of engagement in enhancing the performance, as reflected in the feedback from customers, the more the academics are attached to their work role, and the better they deliver in the classroom. Finally, it indicates the importance of perceived autonomy in affecting both, job resources and work engagement. It could mean that by providing more autonomy to the academics, they employ their own creative teaching methods and enjoy their work.

Along with theoretical contribution, the study has practical implications for its stakeholders, including students, academics and the management of the universities. The results of the current study are expected to create positive changes. For example, it encourages the management of the universities to make policies which enhance coworker support and supervisor support which in turn creates a culture of co-operation. Such informed decisions improve the productivity of the university. This also improves employee-employer bonding and enhances sharing of knowledge with each other. The engaged academics are likely to deliver better in the classrooms, thereby enhancing the competency of students. All these benefits are, however, subject to the degree of autonomy available to the academicians in their workplace.

Despite contribution in the crucial area of academics in India, this study is not free from limitations. Due to 
self-reported questionnaire items, the work engagement construct may have suffered from common-method bias. However, it is argued that engagement is an individuals' perception about himself and hence, self-rating is essential. In addition, service performance of academicians was evaluated by students, thereby leaving less scope for common method bias. Further, the fact that the study is cross-sectional in nature may suffer from some assumptions which can be overcome in a longitudinal study. The study does indicate certain opportunities for future research. For example, longitudinal studies are advisable in the contexts where the association between employees and customers lasts longer as in education. It can also be studied in the context of different industries. Future researchers are therefore, encouraged to generalize the model in a variety of contexts. Finally, it is suggested to investigate whether work engagement has a significant effect on students' evaluation of academics performance even after controlling for constructs such as personality traits and self-concept.

\section{References}

Anderson, C., \& Galinsky, A. D. (2006). Power, optimism, and risk-taking. European Journal of Social Psychology, 36(4), 511-536. http://dx.doi.org/10.1002/ejsp.324

Ashill, N. J., \& Rod, M. (2011). Burnout processes in non-clinical health service encounters. Journal of Business Research, 64(10), 1116-1127. http://dx.doi.org/10.1016/j.jbusres.2010.11.004

ASSOCHAM. (2013). Indian students spend over Rs 10,000 crore on foreign education per year. The Associated Chambers of Commerce and Industry of India. Retrieved August 21, 2014, from http://www.assocham.org/prels/shownews-

Babin, B. J., \& Boles, J. S. (1996). The effects of perceived co-worker involvement and supervisor support on service provider role stress, performance and job satisfaction. Journal of Retailing, 72(1), 57-75. http://dx.doi.org/10.1016/S0022-4359(96)90005-6

Bakker, A. B., Hakanen, J. J., Demerouti, E., \& Xanthopoulou, D. (2007). Job resources boost work engagement, particularly when job demands are high. Journal of Educational Psychology, 99(2), 274-284. http://dx.doi.org/10.1037/0022-0663.99.2.274

Bakker, A. B., \& Demerouti, E. (2008). Towards a model of work engagement. Career Development International, 13(3), 209-223. http://dx.doi.org/10.1108/13620430810870476

Baumruk, R. (2004). The missing link: The role of employee engagement in business success. Workspan, 47(11), 48-52.

Bowen, J., \& Ford, R. C. (2002). Managing service organizations: Does having a "thing" make a difference? Journal of Management, 28(3), 447-469. http://dx.doi.org/10.1177/014920630202800309

Crawford, E. R., LePine, J. A., \& Rich, B. L. (2010). Linking job demands and resources to employee engagement and burnout: A theoretical extension and meta-analytic test. Journal of Applied Psychology, 95(5), 834-848. http://dx.doi.org/10.1037/a0019364

DeConinck, J. B. (2010). The effect of organizational justice, perceived organizational support, and perceived supervisor support on marketing employees' level of trust. Journal of Business Research, 63(12), 1349-1355. http://dx.doi.org/10.1016/j.jbusres.2010.01.003

Gershuny, J., \& Miles, I. (1983). The new service economy: The transformation of employment in industrial societies. London: Frances Pinter.

Gupta, M., \& Kumar, Y. (in-press). Justice and employee engagement: Examining the mediating role of trust in Indian B-schools. Asia-Pacific Journal of Business Administration.

Hackman, J. R., \& Oldham, G. R. (1976). Motivation through the design of work: Test of a theory.

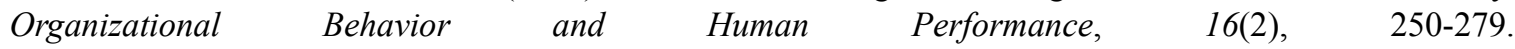
http://dx.doi.org/10.1016/0030-5073(76)90016-7

Hackman, J. R., \& Oldham, G. R. (1980). Work redesign. M.A: Sage publications.

Hakanen, J. J., Bakker, A. B., \& Schaufeli, W. B. (2006). Burnout and work engagement among teachers. Journal of School Psychology, 43(6), 495-513. http://dx.doi.org/10.1016/j.jsp.2005.11.001

Harter, J. K., Schmidt, F. L., \& Hayes, T. L. (2002). Business-unit-level relationship between employee satisfaction, employee engagement, and business outcomes: A meta-analysis. Journal of Applied Psychology, 87(2), 268-279. http://dx.doi.org/10.1037/0021-9010.87.2.268

Hobfoll, S. E. (2001). The influence of culture, community, and the nested-self in the stress process: Advancing 
conservation of resources theory. Applied Psychology, 50(3), 337-421.http://dx.doi.org/10.1111/1464-0597.00062

House, J. S. (1981). Work stress and social support. Reading, MA: Addison-Wesley.

Humphreys, J. H. (2002). Transformational leader behavior, proximity and successful services marketing. Journal of Services Marketing, 16(6), 487-502. http://dx.doi.org/10.1108/08876040210443373

Kahn, W. A. (1990). Psychological conditions of personal engagement and disengagement at work. Academy of Management Journal, 33(4), 692-724. http://dx.doi.org/10.2307/256287

Kahn, W. A. (1992). To be fully there: Psychological presence at work. Human Relations, 45(4), $321-349$. http://dx.doi.org/10.1177/001872679204500402

KPMG. (2014). India union budget 2014: Education post-budget sectoral point of view. KPMG. Retrieved August 21, 2014, from http://www.kpmg.com/IN/en/services/Tax/unionbudget2014/Documents/Education-PoV-2014.pdf

Marinova, D., Ye, J., \& Singh, J. (2008). Do frontline mechanisms matter? Impact of quality and productivity orientations on unit revenue, efficiency, and customer satisfaction. Journal of Marketing, 72(2), 28-45. http://dx.doi.org/10.1509/jmkg.72.2.28

Maslach, C., Schaufeli, W. B., \& Leiter, M. P. (2001). Job burnout. Annual Review of Psychology, 52(1), 397-422. http://dx.doi.org/10.1146/annurev.psych.52.1.397

May, D. R., Gilson, R. L., \& Harter, L. M. (2004). The psychological conditions of meaningfulness, safety and availability and the engagement of the human spirit at work. Journal of Occupational and Organizational Psychology, 77(1), 11-37. http://dx.doi.org/10.1348/096317904322915892

Menguc, B., Auh, S., Fisher, M., \& Haddad, A. (2013). To be engaged or not to be engaged: The antecedents and consequences of service employee engagement. Journal of Business Research, 66(11), 2163-2170. http://dx.doi.org/10.1016/j.jbusres.2012.01.007

Mokaya, S. O., \& Kipyegon, M. J. (2014).Determinants of Employee Engagement in the Banking Industry in Kenya: Case of Cooperative Bank. Journal of Human Resources, 2(2), 187-200. Retrieved from http://aripd.org/journals/jhrmls/Vol_2_No_2_June_2014/12.pdf

Moore, G. H. (1987). The service industries and the business cycle. Business Economics, 12-17. Retrieved from http://www.jstor.org/discover/10.2307/23484196?uid=364844831\&uid=3738256\&uid=2134\&uid=7457432 \&uid $=2 \&$ uid $=70 \&$ uid $=3$ \&uid $=67 \&$ uid $=62 \&$ sid $=21104659935671$

Perrin, T. (2008). Towers Perrin global workforce study 2007-2008: Closing the engagement gap: A road map for driving superior business performance. Retrieved from https:/c.ymcdn.com/sites/www.simnet.org/resource/group/066D79D1-E2A8-4AB5-B621-60E58640FF7B/1 eadership_workshop_2010/towers_perrin_global_workfor.pdf

Rhoades, G., \& Slaughter, S. (2004). Academic capitalism in the new economy: Challenges and choices. American Academic, $\quad 1(1), \quad 37-59 . \quad$ Retrieved from https://69.18.221.209/pdfs/highered/academic/june04/Rhoades.qxp.pdf

Salanova, M., Agut, S., \& Peiró, J. M. (2005).Linking organizational resources and work engagement to employee performance and customer loyalty: The mediation of service climate. Journal of Applied Psychology, 90(6), 1217-1227. http://dx.doi.org/10.1037/0021-9010.90.6.1217

Sand, G., \& Miyazaki, A. D. (2000). The impact of social support on salesperson burnout and burnout components. Psychology \& Marketing, 17(1), 13-26. Retrieved from http://web.a.ebscohost.com/ehost/pdfviewer/pdfviewer?vid=3\&sid=e93a1d8a-301e-40f0-9023-bccb0461e0 $6 \mathrm{~b} \% 40$ sessionmgr4004\&hid $=4106$

Savage, G. T., Blair, J. D., \& Sorenson, R. L. (1989). Consider both relationships and substance when negotiating strategically. The Academy of Management Executive, 3(1), 37-48. http://dx.doi.org/10.5465/AME.1989.4277149

Schaufeli, W. B., Salanova, M., González-Romá, V., \& Bakker, A. B. (2002). The measurement of engagement and burnout: A two sample confirmatory factor analytic approach. Journal of Happiness studies, 3(1), 71-92. http://dx.doi.org/10.1023/A:1015630930326

Schlesinger, L. A., \& Heskett, J. L. (1991). Breaking the cycle of failure in services. Sloan Management Review, 
32(3),

$17-28$.

Retrieved

from http://ikm3000.com/nederlands/pdf/Schlesinger\%20Heskett\%20Sloan\%201991.pdf

Schneider, B., Macey, W. H., Lee, W. C., \& Young, S. A. (2009). Organizational service climate drivers of the American Customer Satisfaction Index (ACSI) and financial and market performance. Journal of Service Research, 12(1), 3-14. http://dx.doi.org/10.1177/1094670509336743

Sonnentag, S. (2003). Recovery, work engagement, and proactive behavior: A new look at the interface between nonwork and work. Journal of Applied Psychology, 88(3), 518-528. http://dx.doi.org/10.1037/0021-9010.88.3.518

Spreitzer, G. M. (1995). Psychological empowerment in the workplace: Dimensions, measurement, and validation. Academy of Management Journal, 38(5), 1442-1465. http://dx.doi.org/10.2307/256865

Stone, D. N., Deci, E. L., \& Ryan, R. M. (2009). Beyond talk: Creating autonomous motivation through self-determination theory. Journal of General Management, 34(3), 75. Retrieved from http://selfdeterminationtheory.org/SDT/documents/2009_StoneDeciRyan_JGM.pdf

Susskind, A. M., Kacmar, K. M., \& Borchgrevink, C. P. (2003). Customer service providers' attitudes relating to customer service and customer satisfaction in the customer-server exchange. Journal of Applied Psychology, 88(1), 179-187. http://dx.doi.org/10.1037/0021-9010.88.1.179

Thomas, K. W., \& Velthouse, B. A. (1990). Cognitive elements of empowerment: An "interpretive" model of intrinsic task motivation. Academy of Management Review, 15(4), 666-681. http://dx.doi.org/10.5465/AMR.1990.4310926

Truss, C., Mankin, D., \& Kelliher, C. (2012). Strategic Human Resource Management. Oxford: Oxford University Press

Wayne, S. J., Shore, L. M., \& Liden, R. C. (1997). Perceived organizational support and leader-member exchange: A social exchange perspective. Academy of Management Journal, 40(1), 82-111. http://dx.doi.org/10.2307/257021

Xanthopoulou, D., Baker, A. B., Heuven, E., Demerouti, E., \& Schaufeli, W. B. (2008). Working in the sky: A diary study on work engagement among flight attendants. Journal of Occupational Health Psychology, 13(4), 345-356. http://dx.doi.org/10.1037/1076-8998.13.4.345

Xanthopoulou, D., Bakker, A. B., Demerouti, E., \& Schaufeli, W. B. (2007). The role of personal resources in the job demands-resources model. International Journal of Stress Management, 14(2), 121-141. http://dx.doi.org/10.1037/1072-5245.14.2.121

\section{Copyrights}

Copyright for this article is retained by the author(s), with first publication rights granted to the journal.

This is an open-access article distributed under the terms and conditions of the Creative Commons Attribution license (http://creativecommons.org/licenses/by/3.0/). 